\title{
Smerte først, så inflammasjon?
}

\section{Bakterier stimulerer smertefibre allerede $f ø r$ det oppstår inflamma- sjon. Dette viser en ny studie på mus.}

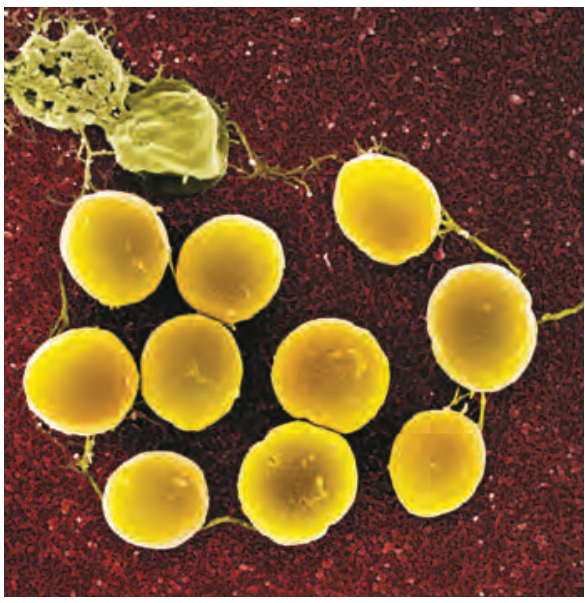

Illustrasjonsfoto: Sciencephoto/NTB scanpix
Nociceptive fibre signaliserer skade og setter i gang forsvarsmekanismer. Det er godt dokumentert at stoffer som dannes ved inflammasjon gir aksjonspotensialer i smertefibre, men dette forklarer ikke reaksjon fra nociceptive fibre $f ø r$ bakterier har satt i gang inflammasjon. Overfølsomhet her gjenspeiler tidsforløpet for bakterieveksten i vevet, ikke utviklingen av inflammasjonen eller immunaktiveringen (1).

For Staphylococcus aureus har forskere vist at $\mathrm{N}$-formylerte peptider og det poredannende toksinet $\alpha$-hemolysin bidrar direkte til hyperalgesi i mus ved å åpne for en kalsiumstrøm inn i nociceptive fibre med spesielle Na-kanaler (1). Bakterieinfiserte, genmanipulerte mus uten disse spesielle nociceptive fibrene var ikke overfølsomme, men hadde til gjengjeld en sterkere inflammasjonsrespons.

- Denne interessante studien viser at bakterier fører til økt sensitivitet for mekaniske og termiske stimuli i nociceptive nervefibre allerede før det kommer en inflammatorisk reaksjon på bakteriene, sier Harald Breivik, professor emeritus ved Akuttklinikken, Oslo universitetssykehus, Rikshospitalet.

- Men en slik hypersensitivitet er ikke det samme som det mennesker opplever som smerte. Forskerne burde derfor ikke bruke uttrykket «hyperalgesi» når det er hypersensitivitet de tester, sier han.

- Mange dyreforsøk har gitt håp om nye smertestillende medikamenter, men når disse prøves ut på mennesker, er de nesten alltid uten effekt. Denne studien er enda et bevis på hvor viktige de nociceptive nervene er for beskyttelse mot inntrengere som kan føre til vevsskade, men det er usikkert om resultatene kan få betydning for smertebehandling hos mennesker, sier Breivik.

\section{Haakon B. Benestad}

Universitetet i Oslo

\section{Litteratur}

1. Chiu IM, Heesters BA, Ghasemlou N et al. Bacteria activate sensory neurons that modulate pain and inflammation. Nature 2013; 501: 52-7.

\section{Kolesterol påvirker forløpet av brystkreft}

\section{Kolesterolmetabolitten 27-hydroksykolesterol fremmer østrogen- reseptoravhengig vekst av humane brystkreftceller.}

Høyt kolesterolnivå gir økt risiko for å få østrogenreseptorpositiv brystkreft og er assosiert med dårligere respons på hormonbehandling. To uavhengige forskergrupper har nylig undersøkt effekten av kolesterolmetabolitten 27-hydroksykolesterol på brystkreft $(1,2)$.

Forskerne viste at både en kultivert human brystkreftcellelinje, MCF7, og humane brystkreftceller implantert i en musemodell vokste raskere i nærvær av 27-hydroksykolesterol. Kolesterolmetabolitten førte også til raskere spredning av svulsten til andre organer. Undersøkelse av humane brystkreftsvulster viste at de mest aggressive kreftsvulstene inneholdt høyere nivåer av enzymet CYP27A1 (som omdanner kolesterol til 27-hydroksykolesterol) enn de mindre aggressive.

- Vi har tidligere vist at ugunstig lipidprofil, for eksempel lavt HDL-kolesterolnivå, kan stimulere brystkreftutvikling og påvirke brystkreftoverlevelse, sier Inger Thune, overlege i onkologi ved Oslo universitetssykehus relatert til inflammatoriske prosesser. og målrettet behandling, sier Thune.

\section{Trine B. Haugen}

Tidsskriftet

\section{Litteratur}

1. Nelson ER, Wardell SE, Jasper JS et al. 27 342: 1094-8 og professor ved Universitetet i Tromsø Norges arktiske universitet. - Samtidig viser studier at ugunstig kolesterolprofil kan være

Selv om forskning på betydningen av kolesterol så langt bare er gjort på brystkreftceller, er det sannsynlig at kolesterolnivået også kan virke inn på utviklingen av andre kreftsykdommer som er assosiert med overvekt. Dette kan gi nye muligheter for forebyggende tiltak, som livsstilssendringer, Hydroxycholesterol links hypercholesterolemia and breast cancer pathophysiology. Science 2013;

2. Wu Q, Ishikawa T, Sirianni $R$ et al. 27-hydroxycholesterol promotes cell-autonomous, ER-positive breast cancer growth. Cell Rep 2013; 5: 637-45.

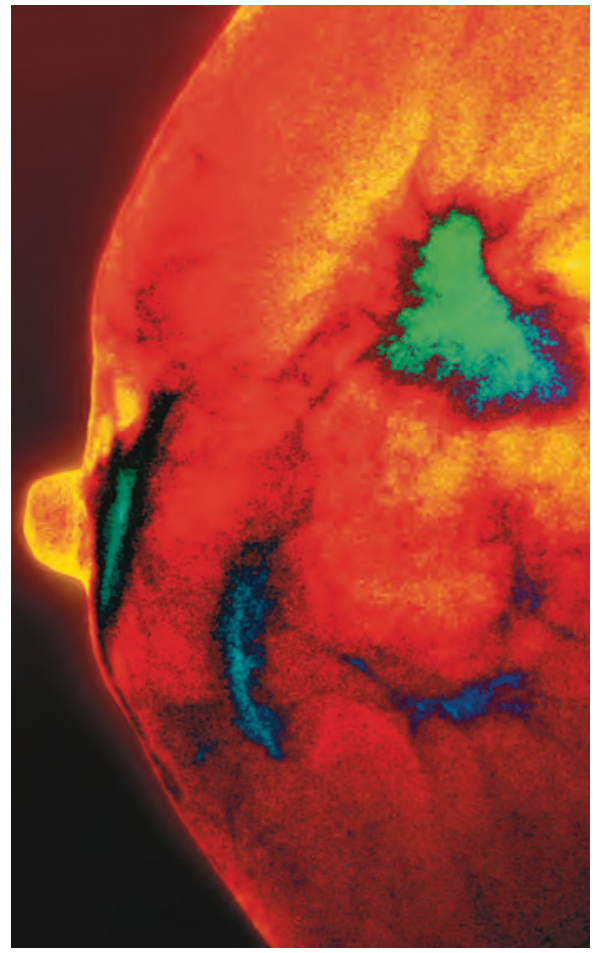

Illustrasjonsfoto: Sciencephoto/NTB scanpix 